Book reviews

Infanticide and the Value of Life

Marvin Kohl, (Ed)

pp. 252. $\$ 15.95$

Prometheus Books

Buffalo, New York, 1978

Increasing control over living and dying has brought great benefits, but it has also created moral and ethical problems of great complexity. As never before, life and death decisions in medical practice have attracted the attention of philosophers, theologians, lawyers and 'professional ethicists'. In this volume on Infanticide, a number of distinguished contributors are joined by three practising doctors whose credentials allow them to write with authority on this complex and emotive issue. In his introduction Dr Kohl is careful to emphasise the distinction between malevolent and benevolent infanticide. It is the latter where the motive is to benefit or help the one who dies that is the focus of attention of most of the contributors. The special problems inherent in deciding the care of infants born with severely handicapping conditions are given special emphasis.

The book consists of four main sections and there are several appendices. In the first two sections infanticide is discussed from the religious, moral, ethical, anthropological, psychological and medical viewpoints. The third section deals with legal issues and the fourth is largely devoted to philosophical discussions on such topics as the value of suffering, voluntary death and meaningless existence, and the worth of human life. The appendices include the British Infanticide Act of 1938 and proposed legislation (by Arval Morris) 'relating to the administration of euthanasia to certain severely defective children suffering from an irremediable condition.' Finally, there is an annotated bibliography of recent relevant books and articles (mainly since 1970).
In a review of this type it is not possible to do justice to the efforts of each contributor. My selection for special mention inevitably reflects my own bias. At times the philosophical arguments are difficult to follow and seem somewhat detached from the cruel tragedies that affect families here and now. Doctors involved in these problems are likely to find the first three sections of special interest and relevance. Opposing views are clearly expressed and the inevitable and necessary compromises are well argued. Joseph Fletcher argues the utilitarian view that justifies infanticide where the good to be gained outweighs the evil. On the other hand, Rabbi Jakobovits emphasises the Jewish commitment to the sanctity of human life which must outweigh all other considerations. Richard Brandt discusses the morality of infanticide and suggests that there is little moral difference between the abortion of a defective child or its killing after birth-a point of indisputable logic that has been taken up by parents of severely defective newborn infants and (for different reasons) by anti-abortion lobbyists. Dr Brandt suggests that 'we may expect that rational benevolent persons deciding which moral code to support would select one that required respect for the life of a normal child but would permit the termination of the life of a severely defective child'. He also emphasises a truth only too apparent to paediatricians-that once the basic decision not to sustain life is taken 'it is mere stupid cruelty to allow it to waste away gradually ...

Dr Peter Black tackles the difficult moral distinction between killing and letting die. He points out that the physician's own view of his role and responsibility will be crucial to any decision he makes. For example, the imperative to relieve suffering might allow killing as legitimately as it does letting die-both will be morally acceptable.

Drs Raymond Duff and Anthony
Shaw, a paediatrician and paediatric $\overparen{D}$ surgeon respectively, discuss these issues from the cotside in the ${ }^{\circ}$ Special Care Nursery where some of $\vec{O}$ the most difficult and most poignant $\overrightarrow{-}$ of these decisions must be taken. $\vec{\omega}$ The view of many paediatricians is expressed by $\mathrm{Dr}$ Shaw when he says 'the most humane manner for or resolving these issues is on a case by $\omega$ case basis whereby parents and $\vec{v}$ physicians reach a decision that $O$ reflects primarily a concern for the $\frac{\text { ? }}{2}$ quality of that newborn life.' $\mathrm{He}$ is bold enough to suggest some of the $c s$ factors that determine the quality of $\frac{\mathbb{D}}{O}$ life for infants. Professor Glanville $\overrightarrow{\mathbb{D}}$ Williams discusses the British 3 Infanticide Act and its application. $\mathbb{D}$ No exactly comparable Act exists in the United States, but an American law professor (Arval Morris), wh pointing out the illegality of many. current practices, suggests that law can be responsive to change as dictated not only by medicine but the common moral judgement of the $\frac{\mathrm{D}}{\mathrm{D}}$ community at large. Between these $\varrho$ two chapters by lawyers is a defence $\vec{\overrightarrow{ }}$ (by Leonard Weber, a professor of $\frac{3}{3}$ religious studies) of the strict legal $\vec{\partial}$ prohibition of infanticide.

Overall, this is an interesting compilation of views on a topic of great importance in these times. The standard of the essays is $\frac{3}{3}$ uniformly high and they are well referenced with useful interpretive $O$ comment. The editor is to be $₹$ congratulated on his blend of topics $ᄋ$ and contributors. In contrast, and considering the price, the quality of book production is very low. It is printed on poor quality paper and $\mathrm{N}$ looks like a cheap novel for the mass market rather than a serious academic publication.

A G M CAMPBELL

\section{Tragic Choices}

Guido Calabresi and Philip Bobbit $252 \mathrm{pp}$. Norton and Company, New York, 1978.

The title of this book, one suspects, $\stackrel{\mathbb{D}}{\stackrel{Q}{2}}$ 